\title{
PELATIHAN MESIN OTOMOTIF BAGI MASYARAKAT DESA SRIKAMULYAN, MENUJU DESA YANG MAJU, MAKMUR DAN MANDIRI
}

\author{
AUTOMOTIVE MACHINE TRAINING FOR CITIZENS \\ SRIKAMULYAN VILLAGE, TOWARDS THE VOCATIONAL \\ FORWARD, PROSPERITY AND INDEPENDENCE
}

\author{
Nana Rahdiana \\ Program Studi Teknik Industri, Fakultas Teknik dan Ilmu Komputer, \\ Universitas Buana Perjuangan Karawang \\ email: nana.rahdiana@ubpkarawang.ac.id
}

\begin{abstract}
ABSTRAK
Desa Srikamulyan adalah satu desa yang terletak di Kecamatan Tirtajaya, Kabupaten Karawang, Propinsi Jawa Barat, dengan jumlah penduduk 7.381 orang, terdiri dari 3.742 lakilaki dan 3.639 perempuan. Kondisi mata pencaharian masyarakat desa Srikamulyan sebagian besar bekerja sebagai nelayan, buruh tani (sebagian besar), pedagang, dan karyawan swasta.

Salah satu upaya meningkatkan tingkat kesejahteraan masyarakat adalah dengan peningkatan SDM terutama para pemuda desa dengan berbagai skill dan keterampilan, yang mampu memotivasi jiwa kewirausahaan. Keberadaan pemuda desa yang tergabung dalam wadah karang taruna sangat diperlukan sebagai penggerak dan agen perubahan.

Program Studi Teknik Industri, Fakultas Teknik dan Ilmu Komputer, Universitas Buana Perjuangan Karawang terpanggil melaksanakan Pengabdian Kepada Masyarakat (PKM), sebagai salah satu kegiatan Tri Dharma Perguruan Tinggi. Kegiatan PKM tahun ini mengusung tema "Pemberdayaan Masyarakat Melalui Pelatihan Servis Kendaraan Bermotor Roda Dua" yang ditujukan bagi Karang Taruna, dengan tujuan pembinaaan kewirausahaan menuju desa yang maju, makmur dan mandiri.
\end{abstract}

Kata Kunci: Srikamulyan, Karang Taruna, Pelatihan, Kewirausahaan

\begin{abstract}
Srikamulyan Village is a village located in Tirtajaya District, Karawang Regency, West Java Province, with a population of 7,381 people, consisting of 3,742 men and 3,639 women. The livelihood conditions of the Srikamulyan village community are mostly working as fishermen, farm laborers (mostly), traders, and private employees.

One effort to improve the level of community welfare is by increasing human resources, especially rural youth with a variety of skills and skills, which are able to motivate the entrepreneurial spirit. The existence of village youth who are members of the youth organization is needed as a driver and agent of change.

Industrial Engineering Program, Faculty of Engineering and Computer Science, University of Buana Perjuangan Karawang is called to carry out "Pengabdian Kepada Masyarakat" (PKM), as one of the three Main Program of University. This year's PKM activity carries the theme "Community Empowerment through Training on Two-Wheeled Motor Vehicle Service" aimed at Youth Organizations, with the aim of fostering entrepreneurship towards developed, prosperous and independent villages
\end{abstract}

\section{9 | Jurnal Buana Pengabdian}


Keywords: Srikamulyan, Youth Organization, Training, Entrepreneurship

\section{PENDAHULUAN}

Desa Srikamulyan adalah satu desa yang terletak di kecamatan Tirtajaya, Kabupaten Karawang, Propinsi Jawa Barat. Letak astronomis desa Srikamulyan pada -6,04767 LS 107,28954 BT. Secara geografis teletak di garis pantai utara yang berdekatan dengan laut jawa dengan tinggi wilayah hanya 5 meter diatas pemukaan laut, dengan jarak tempuh 7,1 km ke ibukota Kecamatan dan 42,4 km ke ibukota Kabupaten (BPS Kabupaten Karawang, Kecamatan Tirtajaya dalam Angka, 2019).

Luas desa Srikamulyan adalah 7,29 $\mathrm{km}^{2}$ atau sekitar 7,90\% dari total wilayah Kecamatan Tirtajaya, memiliki 4 dusun (Kedungasem, Jati Tengah, Ciwaru I dan Cirawu II), 4 Rukun Warga (RW) dan 8 Rukun Tetangga (RT) dengan jumlah Rumah Tangga $2.644 \mathrm{KK}$, dan jumlah penduduk 7.361 orang, terdiri dari 3.739 laki-laki dan 3.622 perempuan (BPS Kabupaten Karawang, Kecamatan Tirtajaya dalam Angka 2019).

Secara geografis desa Srikamulyan memiliki batas wilayah adalah sebagai berikut:

- Sebelah Utara $\quad$ : desa Sedari

- Sebelah Selatan : desa Kedungjeruk

- Sebelah Barat : desa Tambaksumur

- Sebelah Timur $\quad$ : desa Kutamakmur

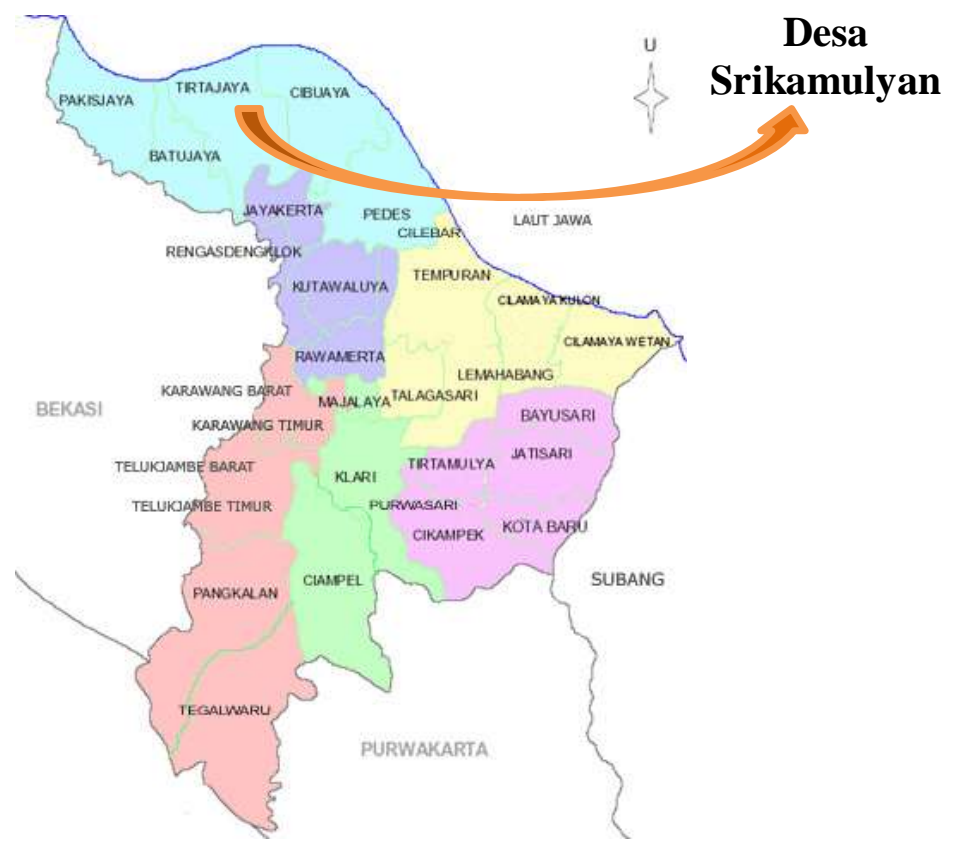


Gambar 1. Peta Desa Srikamulyan, Kecamatan Tirtajaya, Kabupaten Karawang

Desa Srikamulyan dipimpin oleh seorang Kepala Desa. Aparatur desa Srikamulyan memiliki latar belakang pendidikan SD/sederajat berjumlah 17 orang, SLTP/sederajat berjumlah 7 orang dan SMU/sederajat berjumlah 5 orang (BPS Kabupaten Karawang, 2018). Kondisi mata pencaharian masyarakat desa Srikamulyan sebagian besar bekerja sebagai nelayan, buruh tani (sebagian besar), pedagang, dan karyawan swasta.

Keberadaan karang taruna yang mayoritas berisi generasi muda yang produktif sangat diperlukan di tengah-tengah masyarakat sebagai penggerak dan agen perubahan dalam rangka pencapaian tujuan bersama yaitu kesejahteraan masyarakat. Salah satu upaya pencapaian kesejahteraan adalah dengan memperbaiki tingkat perekonomian masyarakat setempat. Oleh karena itu, dibutuhkan pembekalan dan pelatihan yang mendukung upaya tersebut seperti pelatihan-pelatihan keterampilan, kewirausahaan, manajemen bisnis, koperasi, dan lain-lain.

Dengan pelatihan-pelatihan semacam itu diharapkan semangat dan motivasi anggota karang taruna dapat terpacu sehingga akan muncul unit-unit bisnis/usaha yang baru dan dapat memberdayakan masyarakat setempat yang pada akhirnya akan meningkatkan tingkat perekonomian masyarakat. Unit usaha yang dijadikan contoh/model adalah usaha jasa servis kendaraan bermotor roda dua, karena bidang usaha ini peluang masih terbilang lebar dan juga hampir semua orang memiliki sepeda motor sehingga paling tidak setelah mengikuti pelatihan ini untuk tahap awal para peserta dapat memperbaiki/servis sepeda motornya masing-masing.

Tujuan kegiatan pengabdian kepada masyarakat ini adalah sebagai berikut:

1. Memberikan pelatihan keterampilan tentang perawatan/servis kendaraan roda dua kepada anggota Karang Taruna desa Srikamulyan.

2. Untuk mengurangi tingkat pengangguran usia produktif yang tidak memiliki keterampilan di desa Srikamulyan.

3. Untuk mendukung program pemerintah daerah mewujudkan desa Srikamulyan yang maju, makmur dan mandiri. 
Tujuan sesuaikan dengan harapan kepala desa Srikamulyan yang disampaikan pada surat dengan nomor: 145/35/Ds/2019 perihal: Permohonan pelatihan teknik mesin otomotif tahun 2019 tertanggal 01 Juli 2019.

Manfaat kegiatan pengabdian kepada masyarakat yang dikemas dalam bentuk pelatihan servis kendaraan bermotor roda dua, ini adalah sebagai berikut:

1. Bagi karang taruna dan masyarakat desa Srikamulyan

- Meningkatkan pengetahuan dan keterampilan masyarakat khususnya anggota karang taruna desa Srikamulyan tentang perawatan/ servis kendaraan roda dua yang diharapkan menjadi modal awal untuk membuka unit bisnis/ usaha yang baru.

- Diharapkan mampu mengurangi tingkat pengangguran usia produktif yang tidak memiliki keahlian di desa Srikamulyan.

- Diharapkan mampu mendorong terwujudnya desa Srikamulyan yang maju, makmur dan mandiri.

2. Bagi civitas Program Studi Teknik Industri, Fakultas Teknik dan Ilmu Komputer, Universitas Buana Perjuangan Karawang.

- Dapat melaksanakan kegiatan pengabdian kepada masyarakat sebagai bentuk perwujudan Tri Dharma Perguruan Tinggi

- Sebagai bentuk sosialisasi dan kedekatan insan akademik ditengah-tengah masyarakat untuk mendorong program-program pemerintah dalam upaya pembangunan dan peningkatan kesejahteraan masyarakat desa.

\section{METODE}

Pelaksanaan kegiatan pelatihan ini minimalnya akan menggunakan 3 (tiga) metode, yaitu:

1. Metode ceramah

Metode ceramah adalah metode pembelajaran/pelatihan berupa penyampaian paparan materi/teori yang dilakukan oleh tim PKM kepada para peserta pelatihan yang dilakukan di dalam ruangan (aula desa).

2. Metode tanya jawab 
Metode tanya jawab sangat penting bagi para peserta pelatihan, baik disaat menerima penjelasan secara teoritis maupun saat sesi praktik. Metode ini memungkinkan peserta menggali pengetahuan sebanyak-banyaknya tentang halhal lain yang mungkin berhubungan dengan pelatihan tetapi tidak tersampaikan oleh pemateri. Pertanyaan juga bisa diajukan dari pemateri kepada para peserta untuk mengetahui tingkat pemahaman peserta, sekaligus sebagai bahas evaluasi kegiatan.

\section{Metode praktik}

Metode praktik dilakukan setelah sesi teoritis selesai dilaksanakan, dengan tujuan agar peserta lebih memahami materi pelatihan dan mampu melakukan praktik secara langsung teknik perawatan/servis kendaraan bermotor roda dua.

Berikut merupakan tahapan-tahapan yang dilakukan dalam penyelenggaraan kegiatan pengabdian kepada masyarakat ini adalah sebagai berikut:

1. Tahap persiapan

Tahap persiapan yang dilakukan meliputi:

a. Survei

Tahap ini merupakan tahap paling awal yang dilakukan, tim pelaksana mengunjungi tempat sasaran dan berdialog langsung dengan kepala desa dan perwakilan karang taruna desa Srikamulyan. Hal ini penting dilakukan untuk mengetahui dan memahami kondisi daerah yang akan dijadikan sasaran kegiatan dan juga sebagai pendekatan tim terhadap warga. Tindak lanjut dari tahap ini adalah telah diterimanya surat permohonan kegiatan pelatihan dari kepala desa Srikamulyan yang ditujukan ke Universitas Buana Perjuangan Karawang.

b. Pemantapan dan penentuan lokasi dan sasaran

Tahap ini dilakukan dengan cara berkunjung kembali ke tempat sasaran guna menyampaikan dan mensosialisasikan rencana kegiatan yang akan dilakukan serta melakukan pendaftaran terhadap peserta yang akan mengikuti pelatihan.

c. Penyusunan bahan/materi

Tahap ini meliputi penyusunan modul dan presentasi power point yang akan disampaikan. 
d. Persiapan peralatan dan alat peraga

Tahap ini memastikan bahwa peralatan pendukung seperti LCD, sound system, spidol, white board, dan juga alat paraga untuk keperluan praktek seperti peralatan mekanik, sepeda motor yang akan dijadikan peraga praktik tersedia ketika pelaksanaan pelatihan.

2. Tahap pelaksanaan

Tahap pelaksanaan pelatihan dibagi dalam 2 (dua) sesi, yaitu:

a. Sesi pertama

Pada sesi ini akan diberikan penjelasan secara teoritis tentang sistem perawatan kendaraan bermotor roda dua, yang terdiri dari: jenis-jenis servis, peralatan servis, fungsi bagian-bagian dari kendaraan bermotor, cara perawatan kendaraan bermotor, dan teknik perbaikan sepeda motor.

b. Sesi kedua

Pada sesi kedua ini peserta pelatihan akan diajak secara langsung untuk melakukan praktik servis atau perbaikan sepeda motor secara berkelompok, dengan pendampingan oleh dosen dan mahasiswa.

3. Tahap evaluasi

Evaluasi kegiatan dilakukan terhadap aspek pencapaian tujuan pengabdian kepada masyarakat secara keseluruhan; keterlibatan peserta, dan tujuan pelatihan itu sendiri.

\section{HASIL DAN PEMBAHASAN}

Kegiatan pengabdian kepada masyarakat dosen dan mahasiswa Teknik Industri Fakultas Teknik dan Ilmu Komputer, Universitas Buana Perjuangan Karawang, semester ganjil tahun akademik 2019/2020 telah dilaksanakan pada hari Sabtu tanggal 30 Nopember 2019, bertempat di balai desa Srikamulyan, kecamatan Tirtajaya, kabupaten Karawang. Kegiatan ini mengusung tema: "Pemberdayaan Masyarakat Desa melalui Pelatihan dan Pengelolaan Kendaraan Bermotor Roda Dua”.

Tabel 1. Peserta Pelatihan Kegiatan Pengabdian Kepada Masyarakat

\begin{tabular}{c|c|l|l}
\hline No & Nomor KTP & \multicolumn{1}{|c|}{ Nama Peserta } & \multicolumn{1}{c}{ Keterangan } \\
\hline 1 & 3215091502810004 & Ade Saron & Karang Taruna Ds. Srikamulyan \\
\hline 2 & 3215090510880008 & Samsudin & Karang Taruna Ds. Srikamulyan \\
\hline 3 & 3215090504800006 & Nurjamil & Karang Taruna Ds. Srikamulyan \\
\hline
\end{tabular}




\begin{tabular}{c|l|l|l}
\hline 4 & 3215092912930002 & Abdurohman & Karang Taruna Ds. Srikamulyan \\
\hline 5 & 3215091507930004 & Suheri & Karang Taruna Ds. Srikamulyan \\
\hline 6 & 3215091511930006 & Mustika & Karang Taruna Ds. Srikamulyan \\
\hline 7 & 3215091405950005 & Dede Hidayat & Karang Taruna Ds. Srikamulyan \\
\hline 8 & 3215090107940112 & Asep & Karang Taruna Ds. Srikamulyan \\
\hline 9 & 3215092102960002 & Badru Jamal & Karang Taruna Ds. Srikamulyan \\
\hline 10 & 3215091204880009 & Rohman & Karang Taruna Ds. Srikamulyan \\
\hline 11 & 3215090107940112 & Samsul Hadi & Karang Taruna Ds. Srikamulyan \\
\hline 12 & 3215112203910003 & Riswanto & Karang Taruna Ds. Srikamulyan \\
\hline 13 & 3215090903910007 & Andriansyah & Karang Taruna Ds. Srikamulyan \\
\hline 14 & 3215091205910004 & Wartam Hidayat & Karang Taruna Ds. Srikamulyan \\
\hline 15 & 3215092809000003 & Yudi & Karang Taruna Ds. Srikamulyan \\
\hline
\end{tabular}

Untuk memudahkan dan memperlancar kegiatan pelatihan, khususnya saat praktik dan menyesuaikan dengan media praktik yang sudah disiapkan panitia yaitu 5 (lima) unit motor, maka peserta dibagi dalam lima tim, yaitu:

Tabel 2. List Peserta Pelatihan dalam Bentuk Tim

\begin{tabular}{|c|c|c|c|c|}
\hline Tim & $\begin{array}{l}\text { Peserta } \\
\text { Pelatihan } \\
\end{array}$ & Dosen Pendamping & $\begin{array}{l}\text { Mahasiswa } \\
\text { Pendamping }\end{array}$ & Jenis Motor \\
\hline \multirow[t]{3}{*}{ Tim A } & Ade Saron & \multirow[t]{3}{*}{ Nana Rahdiana } & Falahal Majid & \multirow[t]{3}{*}{ Jupiter MX } \\
\hline & Samsudin & & Gusti Pratama & \\
\hline & Nurjamil & & Roy Purba & \\
\hline \multirow[t]{3}{*}{ Tim B } & Abdulrohman & \multirow[t]{3}{*}{ Sunandar } & Fajar A Fauzi & \multirow[t]{3}{*}{ Honda Beat } \\
\hline & Suheri & & Rangga Permana & \\
\hline & Mustika & & Dimas Rizqie & \\
\hline \multirow[t]{3}{*}{ Tim C } & Dede Hidayat & \multirow[t]{3}{*}{ Afif Hakim } & Eko Afriyansyah & \multirow[t]{3}{*}{ Honda Revo } \\
\hline & Asep & & Diki Herdiansyah & \\
\hline & Badru Jamal & & Tito C. Pratama & \\
\hline \multirow[t]{3}{*}{ Tim D } & Rohman & \multirow[t]{3}{*}{ Sumanto } & Iqbal Maulana & \multirow[t]{3}{*}{ Yamaha X-Ride } \\
\hline & Samsul Hadi & & Deri & \\
\hline & Riswanto & & Muhamad Ichwan & \\
\hline \multirow[t]{3}{*}{ Tim E } & Andriansyah & \multirow[t]{3}{*}{ Khoerudin } & Ridho & \multirow[t]{3}{*}{ Honda Supra } \\
\hline & W. Hidayat & & Riyan Ardianto & \\
\hline & Yudi & & Ragil & \\
\hline
\end{tabular}

Berikut adalah beberapa foto kegiatan selama kegiatan berlangsung.

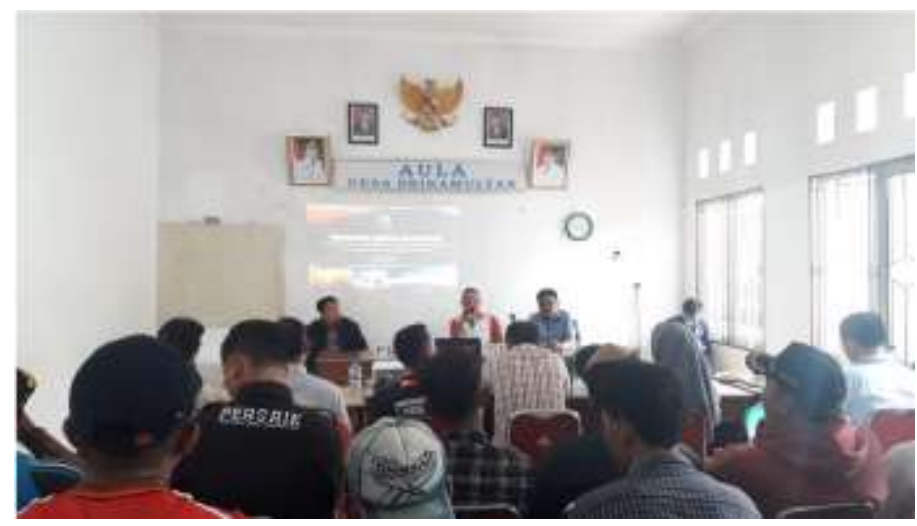

Gambar 2. Acara Pembukaan Pelatihan 


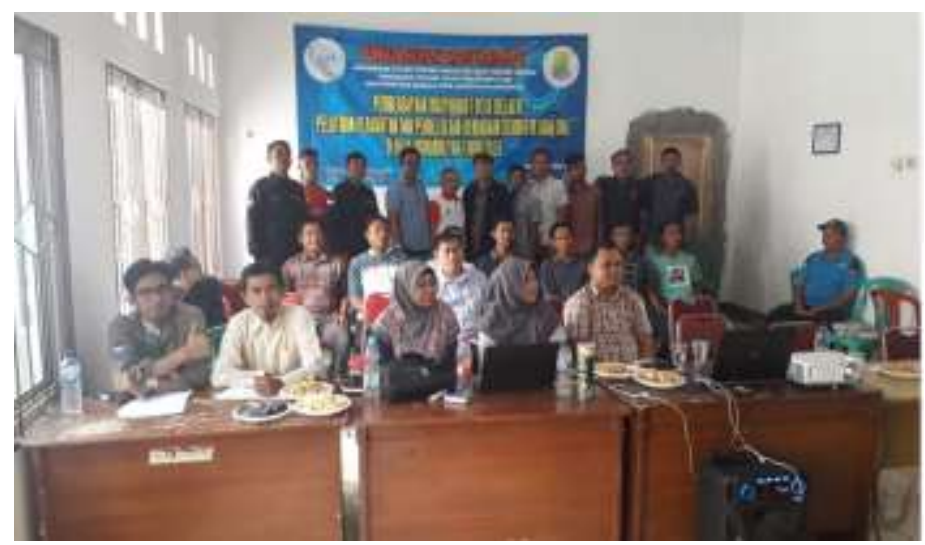

Gambar 3. Foto Bersama dengan Peserta Pelatihan

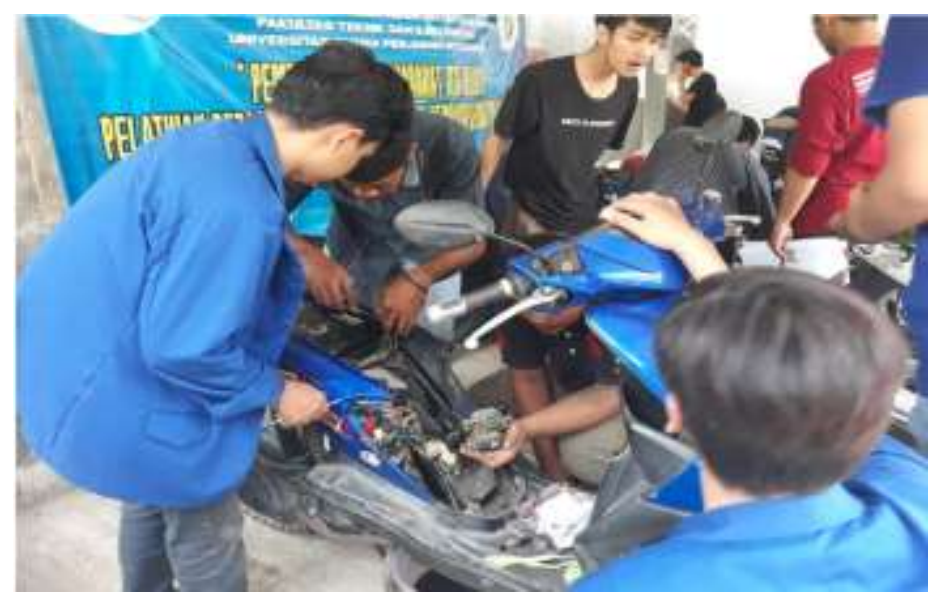

Gambar 4. Praktik Pelatihan Servis Kendaraan Roda Dua

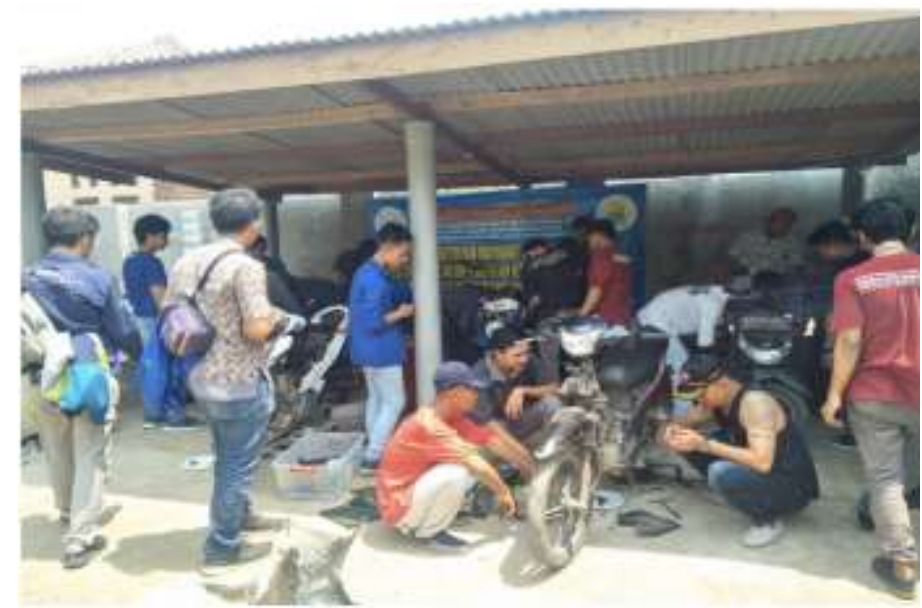

Gambar 5. Suasana Praktik Pelatihan Servis Bermotor Roda Dua 
Untuk memastikan kegiatan pelatihan berjalan dengan aman dan lancar, maka sebelum pelatihan berlangsung dilakukan briefing. Ada berapa hal yang disampaikan, yaitu:

1. Kerjasama tim,

2. Selalu mengutamakan keamanan (safety), khususnya tidak diperkenakan meroko selama praktik berlangsung.

3. Lakukan prinsip 5R (Ringkas, Rapih, Resik, Rawat, dan Rajin), sehingga selesai pelatihan peralatan tidak disimpan dimana saja, dan tempat pelatihan tetap bersih.

4. Sebelum praktik dilaksanakan, lakukan pengisian item cek list sesuai dengan lembar cek list yang sudah disiapkan panitia.

Tabel 3. Item Checklist Service Motor

\begin{tabular}{c|l|l|l|l|l}
\hline \multirow{2}{*}{ No Item } & \multicolumn{1}{c|}{ Kondisi } & \multirow{2}{*}{ Ket. } \\
\cline { 4 - 5 } & & Bagus & $\begin{array}{c}\text { Layak } \\
\text { Pakai }\end{array}$ & Ganti & \\
\hline & Cek suspensi & & & & \\
\hline 2 & Fungsi kelistrikkan (Lampu) & & & & \\
\hline 3 & Gerak bebas kemudi & & & & \\
\hline 4 & Tegangan baterai & & & & \\
\hline 5 & Pemerikasaan rem & & & & \\
\hline 6 & Stel handle gas & & & & \\
\hline 7 & Stel tuas kopling & & & & \\
\hline 8 & Oli mesin & & & & \\
\hline 9 & Periksa roda dan jari-jari & & & & \\
\hline 10 & Kelayakan ban & & & & \\
\hline 11 & Tekanan ban & & & & \\
\hline 12 & Stel rantai & & & & \\
\hline 13 & Periksa baut pengikat & & & & \\
\hline 14 & Saringan udara & & & & \\
\hline 15 & Cek karburator & & & & \\
\hline 16 & Cek filter oli & & & & \\
\hline 17 & Pemeriksaan air radiator & & & \\
\hline 18 & Pemeriksaan busi & & & \\
\hline 19 & Penyetelan klep & & & \\
\hline 20 & Pemeriksaan saringan CVT & & & \\
\hline 21 & Pemeriksaan oli gear & & & \\
\hline
\end{tabular}

Catatan: Berikan tanda $\sqrt{ }$ pada kolom kondisi sesuuai hasil pengecekan

Kegiatan pengabdian kepada masyarakat pada semester ganjil tahun akademik 2019/2020, tim telah melakukan identifikasi faktor-faktor pendukung dan penghambat kegiatan diantaranya yaitu: 
A. Faktor Pendukung

Beberapa faktor pendukung yang memperlancar kegiatan pengabdian kepada masyarakat di desa Srikamulyan pada tanggal 30 Nopember 2019, adalah sebagai berikut:

1. Adanya dukungan penuh dari Universitas Buana Perjuangan Karawang, khususnya Lembaga Penelitian dan Pengabdian Masyarakat (LPPM).

2. Adanya dukungan penuh pihak desa Srikamulyan, khususnya dari Kepala Desa dan Karang Tarunanya.

3. Tim yang solid dari dosen dan mahasiswa.

4. Kolaborasi dan koordinasi antara Universitas, LPPM, Fakultas, Program Studi, dosen dan mahasiswa berjalan sangat baik dan efektif, sehingga tahapan-tahapan kegiatan mulai dari persiapan, pelaksanaan dan pelaporan dapat berjalan dengan baik pula.

B. Faktor Penghambat

Sementara yang menjadi faktor penghambat kegiatan pengabdian kepada masyarakat di desa Srikamulyan pada tanggal 30 Nopember 2019, dapat dikatakan hampir tidak, semua berjalan sesuai rencana. Hanya sedikit miss komunikasi kehadiran peserta pelatihan yang seharusnya acara dapat dimulai jam 08.00 wib mundur 1 jam dikarenakan peserta baru datang jam 09.00 wib sesuai dengan surat undangan yang dibuat pihak Karang Taruna kepada para peserta.

\section{KESIMPULAN DAN SARAN}

A. Kesimpulan

Dari hasil kegiatan pengabdian kepada masyarakat di desa Srikamulyan melalui pelatihan servis kendaraan bermotor roda dua, kami dapat mengambil beberapa kesimpulan sebagai berikut:

1. Kegiatan pengabdian kepada masyarakat berjalan sangat baik dan sesuai dengan rencana dan harapan tim pelaksana.

2. Kegiatan pengabdian yang dikemas dalam bentuk pelatihan yang mengkombinasikan teori dan praktik dinilai sangat efektif, karena peserta dapat secara langsung mempraktikannya keterampilannya tanpa rasa ketakutan gagal atau rusak, karena kegiatan praktik dalam bimbingan tim pelaksana. 
3. Pelatihan ini telah mampu memberikan pengetahuan dan keterampilan anggota karang taruna mengenai teknis perawatan/servis kendaraan bermotor roda dua.

B. Saran

Agar supaya target luaran dari setiap kegiatan pengabdian kepada masyarakat ini dapat dicapai dengan baik, maka tim pelaksana memiliki beberapa saran sebagai berikut:

1. Perlu kiranya dilakukan pelatihan yang lebih intensif untuk lebih memantapkan keterampilan dari tiap-tiap peserta sehingga tumbuh jiwa kewirausahaan, mengingat peluang untuk usaha bengkel sepeda motor sangat potensial.

2. Perlu adanya tindak lanjut dari pemerintah desa untuk terus memotivasi pemudapemuda desa pada umumnya dan anggota karang taruna pada khususnya dalam upaya menumbuh kembangkan jiwa kewirausahaan.

\section{DAFTAR PUSTAKA}

[1]. BPS Karawang (2019). Kecamatan Tirtajaya dalam Angka 2019. Badan Pusat Statistik Kabupaten Karawang.

[2]. Kementerian Pendidikan dan Kebudayaan Republik Indonesia (2015). Pemeliharaan Mesin Sepeda Motor Roda 2.

[3]. Panduan Pengabdian Kepada Masyarakat (2019). Lembaga Penelitian dan Pengabdian Masyarakat, Universitas Buana Perjuangan Karawang. 